\title{
ANALISIS PENGARUH KARAKTERISTIK PERUSAHAAN TERHADAP INTELLECTUAL CAPITAL DISCLOSURE PERUSAHAAN KEUANGAN DI BEI
}

\author{
Agung Sri Wardhani \\ Program Studi Akuntansi Politeknik Ubaya \\ Jalan Ngagel Jaya Selatan 169, Surabaya
}

\begin{abstract}
The purpose of this research is to test the impact level of intellectual capital disclosure on annual financial statements of listed financial companies in Indonesian Stock Exchange. This research has two variables. The first variable is the intellectual capital disclosure as the dependent variable. The second variable is the characteristics of the company (leverage, ownership concentration, type of external auditor, age of listing, independent commissioner, size of the audit committee, and size of the company) as the independent variable. The sample of this research are chosen by using the sampling purposive method. The classic assumption test is used earlier to validate the variables, and the result showed that the variables are valid. The result of this research shows that average rate of intellectual capital disclosure is 37,9\%. Multiple regression analysis is used to test the hypothesis. Based on the statistics test result, the independent variable (leverage, ownership concentration, type of external auditor, age of listing, independent commissioner, size of the audit committee, and size of the company) doesn't have significant effect on intellectual capital disclosure. It concludes that intellectual capital disclosure hasn't been much revealed on financial companies in Indonesia.
\end{abstract}

\footnotetext{
ABSTRAK

Penelitian ini bertujuan untuk menguji pengaruh tingkat intellectual capital disclosure pada laporan tahunan perusahaan keuangan yang terdaftar di Bursa Efek Indonesia (BEI). Dalam penelitian ini terdapat 2 variabel yaitu intellectual capital disclosure sebagai variabel dependen dan karakteristik perusahaan (leverage, konsentrasi kepemilikan, tipe auditor eksternal, umur listing, komisaris independen, ukuran komite audit dan ukuran perusahaan) sebagai variabel independen. Sampel penelitian dipilih dengan menggunakan metode purposive sampling. Dalam penelitian ini terlebih dahulu dilakukan uji asumsi klasik, untuk menguji keabsahan dari variabel yang akan diujikan. Hasil uji menyatakan bahwa variabel layak untuk diuji. Hasil penelitian menunjukkan bahwa tingkat rata-rata intellectual capital disclosure hanya sebesar 37,9\%. Analisis regresi ganda digunakan untuk menguji hipotesis. Berdasarkan hasil uji statistik yang dilakukan menyatakan bahwa variabel independen yang diujikan berupa (leverage, konsentrasi kepemilikan, tipe
} 
auditor eksternal, umur listing, komisaris independen, ukuran komite audit dan ukuran perusahaan) tidak memiliki pengaruh yang signifikan terhadap tingkat intellectual capital disclosure. Hal itu menyimpulkan bahwa intellectual capital disclosure belum banyak diungkapkan pada perusahaan keuangan di Indonesia.

Keywords: intellectual capital disclosure, characteristics of the company, leverage, ownership concentration, type of external auditor, age of listing, independent commissioner, size of the audit committee, and size of the company.

\section{PENDAHULUAN}

Laporan keuangan perusahaan haruslah menyajikan data yang benar dan akurat. Penyajian yang benar dan akurat harus sesuai dengan prinsip akuntansi yang dapat diterima secara umum. Penyajian laporan keuangan untuk perusahaan dagang dan perusahaan manufaktur sedikit berbeda dengan penyajian laporan keuangan pada perbankan. Terdapat beberapa aturan tambahan dalam menyajikan laporan keuangan perbankan dan lembaga keuangan.

Aturan dalam menyajikan laporan keuangan perbankan diatur di dalam PAPI (Peraturan Akuntansi Perbankan Indonesia). Di Indonesia yang bertindak sebagai pengatur/regulator perbankan adalah Bank Indonesia. Mengenai hal tersebut Putnis (2012) mengungkapkan sebagai berikut: "all banks must submit to Bank Indonesia all information and explanation on their business, including annual balance sheets and profit/loss statement (audited by public accountant) along with their explanation, as well as other periodical reports, according to the procedure stipulated their explanations, as well as other periodical report, according to the procedure stipulated by Bank Indonesia."
Namun demikian penyajian laporan keuangan haruslah menyajikan informasi yang relevan, terpercaya dan tepat waktu. Laporan keuangan yang saat ini disusun masih banyak yang menyajikan berdasarkan pada tenaga kerja (labor-based business). Informasi berdasarkan pengetahuan (knowledgebased business) masih jarang diungkapkan dalam penyusunan laporan keuangan di Indonesia.

Penyajian laporan keuangan perbankan seharusnya lebih ditekankan pada pengetahuan (knowledge-based business). Dengan knowledge yang dimiliki diharapkan perusahaan dapat mengembangkan sumber daya lain yang dimilikinya secara lebih efisien dan ekonomis. Li et al. (2008) mengungkapkan bahwa pengakuan intellectual capital memiliki signifikansi yang lebih besar dalam menciptakan keunggulan kompetitif dan nilai bagi para pemegang saham (Li et al., 2008). Tayles et al. (2007) juga menyatakan bahwa "intellectual capital is increasingly recognised as having much greater significance in creating and maintaining competitive advantage and shareholder value." Pernyataan tersebut menyatakan bahwa pengungkapan intellectual/pengetahuan dinilai dapat menciptakan keunggulan kompetitif. 


\begin{abstract}
Alasan lain pentingnya pengungkapan intellectual/pengetahuan dalam penyajian laporan keuangan adalah adanya penelitian yang dilakukan oleh Price Waterhouse-Coopers (Eccles et al., 2001 dalam Bozzolan et al., 2003). Hasil penelitian tersebut menunjukkan bahwa dari 10 jenis informasi yang dibutuhkan pengguna laporan keuangan, 5 diantaranya terkait dengan pengungkapan intellectual. Informasi tersebut adalah market growth, quality/experience of the management team, market size, market share, and speed to market. Penelitian Bozzolan et al. (2003) menyatakan bahwa kenyataannya tipe informasi yang dibutuhkan oleh investor tersebut tidak diungkapkan, sehingga menyebabkan terjadinya "information gap" dalam menyajikan laporan keuangan.
\end{abstract}

Berdasarkan latar belakang tersebut, maka dalam penelitian ini akan diuji dan dianalisis pengaruh karakteristik perusahaan terhadap intellectual capital disclosure dalam laporan tahunan perusahaan keuangan yang terdapat pada website Bursa Efek Indonesia (BEI) dengan alamat www. idx.co.id. Tujuan dalam melakukan penelitian ini adalah untuk menguji dan menganalisis apakah karakteristik perusahaan yang meliputi tingkat leverage perusahaan, konsentrasi kepemilikan, pengaruh auditor eksternal, umur listing perusahaan, komisaris independen, ukuran komite audit dan ukuran perusahaan memiliki pengaruh yang signifikan terhadap pengungkapan sukarela intellecttual capital pada perusahaan keuangan yang terdaftar di Bursa Efek Indonesia (BEI) pada tahun 2010.

\section{TINJAUAN PUSTAKA \\ Intellectual Capital}

Konsep Intellectual Capital merupakan konsep yang sulit untuk diterapkan, namun demikian konsep tesebut, sangat perlu dikembangkan, mengingat saat ini perkembangan mengarah kepada human resources. Menurut Pablos (2005) dalam Whiting and Woodcock (2011) intellectual capital dimaknai dengan 2 makna. Pertama sebagai perbedaan nilai pasar (market value) dan nilai buku (book value) perusahaan dan kedua sebagai sumber daya pengetahuan yang berkontribusi terhadap penciptaan keuntungan yang kompetitif bagi perusahaan.

Sedangkan menurut $\mathrm{Li}$ et al. (2008) intellectual capital adalah "the possession of knowledge and experience, professional knowledge and skill, good relationship, and technological capacities, which when applied will give organizations competitive advantages". Hal tersebut menjelaskan bahwa perusahaan atau organisasi memiliki pengetahuan dan pengalaman, pengetahuan profesional dan keterampilan, hubungan yang baik, dan kapasitas teknologi, yang bila diterapkan dapat memberikan perusahaan/ organisasi keuntungan kompetitif.

\section{Karakteristik Perusahaan}

Menurut Suhardjanto dan Wardhani (2010) karakteristik perusahaan merupakan ciri-ciri khusus yang melekat pada perusahaan, menandai sebuah perusahaan dan membedakannya dengan perusahaan lain. Dalam penelitian ini karakteristik perusahaan dilihat dari ke delapan ciri yaitu jenis industri, tingkat leverage, konsentrasi kepemilikan, auditor eksternal, umur listing, komisaris independen, komite audit dan ukuran perusahaan. 


\section{Penelitian Terdahulu}

Penelitian Whiting and Woodcock (2011) di Australia menunjukkan hasil bahwa intellectual capital disclosure akan rendah pada kategori eksternal capital. Intellectual capital disclosure berpengaruh pada perusahaan yang berbasis teknologi dan perusahaan yang diaudit oleh Kantor Akuntan Publik yang tergolong The Big Four. Kepemilikan konsentrasi, leverage dan listing age tidak mempengaruhi intellectual capital disclosure.

Hasil penelitian Branco et al. (2010) di Portugal menunjukkan bahwa size signifikan dalam menjelaskan intellectual capital disclosure. Hasil penelitian juga menunjukkan bahwa afiliasi industri hanya sebagian yang dapat menjelaskan mengenai intellectual capital disclosure. Time dan level pengungkapan tidak dapat menjelaskan hubungan dengan intellectual capital disclosure.

Menurut Bruggen et al. (2009) dari hasil penelitian di Australia menunjukkan bahwa jenis industri, size memainkan peran yang penting sebagai penentu intellectual capital disclosure. Sedangkan tingkat informasi asimetri tidak menemukan hubungan terhadap intellectual capital disclosure.

\section{HIPOTESIS PENELITIAN}

Hipotesis yang diajukan dalam penelitian ini adalah sebagai berikut:

H1 : Ada pengaruh positif yang signifikan dari leverage terhadap intellectual capital disclosure.

H2 : Ada pengaruh negatif yang signifikan dari konsentrasi kepemilikan terhadap intellectual capital disclosure.
H3 : Ada pengaruh positif yang signifikan dari auditor eksternal terhadap intellectual capital disclosure.

H4 : Ada pengaruh negatif yang signifikan dari umur listing perusahaan terhadap intellectual capital disclosure.

H5 : Ada pengaruh positif yang signifikan dari proporsi komisaris independen terhadap intellectual capital disclosure.

H6 : Ada pengaruh positif yang signifikan dari ukuran komite audit terhadap intellectual capital disclosure.

H7 : Ada pengaruh positif yang signifikan dari ukuran perusahaan terhadap intellectual capital disclosure.

\section{METODE PENELITIAN \\ Sampel Penelitian}

Teknik pengambilan sampel dalam penelitian ini didasarkan pada teknik purposive sampling, yaitu pengambilan sampel yang didasarkan pada suatu pertimbangan dan atau tujuan tertentu yang diinginkan oleh peneliti dalam penelitian.

Sampel penelitian yang digunakan didasarkan pada seluruh populasi perusahaan keuangan yang terdaftar di Bursa Efek Indonesia (BEI) pada tahun 2010. Kriteria pengambilan sampel harus memenuhi kriteria sebagai berikut:

1. Perusahaan telah mempublikasikan laporan tahunan (annual report) lengkap pada tahun 2010 di situs resmi Bursa Efek Indonesia.

2. Mempublikasikan laporan keberlanjutan (sustainability reporting) atau mengungkapkan (disclosure) infor- 
masi tanggung jawab sosial lainnya selama tahun 2010 dalam laporan tahunan (annual report).

3. Data perusahaan yang dibutuhkan untuk penelitian ini tersedia sesuai dengan variabel yang digunakan dalam penelitian.

\section{Variabel Penelitian}

Variabel penelitian yang digunakan dalam penelitian ini terdiri dari 2 kelompok variabel, yaitu kelompok variabel dependen hanya ada 1 variabel, yaitu Intellectual Capital Disclosure dan kelompok variabel independen yang terdiri dari 7 variabel yaitu Tingkat Leverage, Konsentrasi Kepemilikan, Pengaruh Auditor Eksternal, Umur Listing Perusahaan, Komisaris Independen, Ukuran Komite Audit dan Ukuran Perusahaan.

\section{Pengukuran Variabel Penelitian Intellectual Capital}

Dalam penelitian ini intellectual capital diukur berdasarkan penelitian yang dilakukan oleh Bukh et al. (2005). Rumus indeks pengungkapan yang dipakai oleh Bukh et al. (2005) adalah sebagai berikut:

$$
I C D I_{j}=\frac{\sum_{j=1}^{n_{j}} X_{i j}}{n_{j}}
$$

Keterangan:

$\mathrm{ICDIj}=$ Indeks pengungkapan IC

$\mathrm{Nj} \quad=$ Jumlah item untuk $\mathrm{j}$ tahun perusahaan 81 item

$\mathrm{Xij}=1$ jika item ith diungkapkan, 0 jika item ith tidak diungkapkan, jadi:

$$
0 \leq \operatorname{ICDIj} \leq 1
$$

Item pengungkapan intellecual capital berdasarkan penelitian yang telah dilakukan oleh Bukh et al. (2005) terlihat pada Tabel 1 .

Tabel 1

Jumlah Item Intellectual Capital Disclosure

\begin{tabular}{|c|l|c|}
\hline No. & \multicolumn{1}{|c|}{ Keterangan } & $\begin{array}{c}\text { Jumlah } \\
\text { Item }\end{array}$ \\
\hline 1. & Employees & 27 \\
\hline 2. & Customers & 14 \\
\hline 3. & Information technology & 5 \\
\hline 4. & Processes & 8 \\
\hline 5. & Research and development & 9 \\
\hline 6 & Strategic statement & 15 \\
\hline & TOTAL & $\mathbf{7 8}$ \\
\hline
\end{tabular}

Sumber: Bukh et al. (2005)

\section{Tingkat Leverage}

Tingkat leverage yang digunakan dihitung menggunakan Debt To Equity Ratio (DER) perusahaan keuangan yang dijadikan sampel pada tahun 2010. Nilai leverage dapat dihitung dengan rumus sebagai berikut:

\footnotetext{
Total hutang perusahaan $\mathrm{i}$ pada periode $\mathrm{t}$ Leverage $=$

Total ekuitas perusahaan i pada periode $\mathrm{t}$
}

\section{Konsentrasi Kepemilikan}

Konsentrasi kepemilikan pada penelitian diukur menggunakan ukuran dari hak suara distribusi terbesar baik kepada pemilik atau manajer yang dimiliki pada akhir periode 2010 .

\section{Pengaruh Auditor Eksternal}

Yang dimaksud auditor eksternal dalam penelitian ini adalah perusahaan keuangan yang menggunakan jasa Kantor Akuntan Publik (KAP) yang 
tergolong The Big Four sebagai perusahaan audit untuk mengaudit annual report perusahaan perbankan tersebut pada tahun 2010 .

\section{Umur Listing Perusahaan}

Umur listing perusahaan pada penelitian ini didasarkan pada Keputusan Direksi PT Bursa Efek Jakarta No: Kep-305/BEJ/07-2004, pasal I.16 yang menjelaskan bahwa pencatatan (listing) adalah pencantuman suatu efek dalam daftar efek yang tercatat di Bursa sehingga dapat diperdagangkan di Bursa.

\section{Komisaris Independen}

Komisaris independen dalam penelitian ini adalah sekelompok orang yang dipilih atau ditunjuk untuk mengawasi kegiatan suatu perusahaan atau organisasi, yang tercatat dalam tata kelola perusahaan pada periode tahun 2010.

\section{Ukuran Komite Audit}

Komite Audit dalam penelitian ini didasarkan pada Keputusan Ketua BAPEPAM No.Kep-29/PM/2004:No. IX.I.5, tentang Pembentukan dan Pedoman Pelaksanaan Kerja Komit Audit, yaitu suatu komite yang dibentuk oleh Dewan Komisaris dalam rangka membantu melaksanakan tugas dan fungsinya pada perusahaan perbankan periode 2010 .

\section{Ukuran Perusahaan}

Ukuran perusahaan dalam penelitian ini adalah besarnya kekayaan perusahaan yang ditunjukkan dengan nilai total aktiva dalam neraca akhir perusahaan perbankan yang terdaftar di BEI pada tahun 2010.

\section{Teknik Analisis Data}

Pengujian hipotesis penelitian $\mathrm{H} 1, \mathrm{H} 2, \mathrm{H} 3, \mathrm{H} 4, \mathrm{H} 5, \mathrm{H} 6$ dan $\mathrm{H} 7$ menggunakan model regresi dengan bantuan software statistik SPSS 19 . Adapun persamaan regresi berganda yang digunakan dalam penelitian ini sebagai berikut:

Total_ICD $=\beta 0+\beta 1 \mathrm{LEVi}+\beta 2 \mathrm{CON}-$ OWNi $+\beta 3$ AUDit $+\beta 4$ AGE $+\beta 5$ INEDi + $\beta 6 S A C i+\beta 7 S I Z E i+\varepsilon i$.

\section{Keterangan:}

Total_ICD $=$ Total intellectual capital disclosure

BO $=$ Koefisien arah regresi (konstanta) $\beta 1=$ Koefisien arah regresi variabel tingkat leverage

$\beta 2=$ Koefisien arah regresi variabel konsentrasi kepemilikan

$\beta 3=$ Koefisien arah regresi variabel pengaruh auditor eksternal

ß4 = Koefisien arah regresi variabel umur perusahaan

$\beta 5=$ Koefisien arah regresi variabel komisaris independen

$\beta 6=$ Koefisien arah regresi variabel ukuran komite audit

$\beta 7=$ Koefisien arah regresi variabel ukuran perusahaan

$\mathrm{LEV}=$ Leverage

CON_OWN $=$ Konsentrasi Kepemilikan

AUD $=$ Auditor eksternal

AGE = Log natural dari lamanya listing di bursa

INED $=$ Proporsi komisaris independen, $\mathrm{SAC}=$ Ukuran komite audit

SIZE $=$ Ukuran perusahaan

$\mathrm{Ei}=$ Error time

$\mathrm{I}=$ Tahun ke-i 


\section{HASIL PENELITIAN \\ Data penelitian}

Objek penelitian yang digunakan dalam penelitian ini adalah seluruh perusahaan keuangan yang tercatat di Bursa Efek Indonesia (BEI) pada periode 2010 , dengan persyaratan perusahaan melaporkan annual report tahun 2010 dan mengungkapkan informasi mengenai tanggung jawab sosial (sustainability report) untuk tahun 2010.

Pada tahun 2010 terdapat 23 perusahaan yang bergerak di bidang perbankan dan 6 perusahaan lembaga keuangan non bank yang terdaftar di Bursa Efek Indonesia yang memiliki annual report dan informasi mengenai sustainability report.

\section{Analisis Statistik Deskriptif}

Analisis statistik deskriptif digunakan untuk mengetahui karakteristik sampel dalam penelitian. Berdasarkan perhitungan statistik diketahui bahwa pengungkapan intellectual capital minimum sebesar 0,18 yaitu Panin Financial Tbk. dan maksimum dilakukan oleh bank CIMB Niaga Tbk. sebesar 0,64 . Rata-rata perusahaan mengungkapkan intellectual capital hanya sebesar 0,40.

Dari data hasil statistik deskriptif seperti terlihat pada Tabel 2 dapat diketahui pengungkapan maksimum dan minimum variabel independen seperti berikut ini:

1. Variabel independen X1 yaitu variabel Leverage (LEV) yang menunjukkan tingkat Leverage dengan nilai minimum sebesar 0,45 dan nilai maksimun sebesar 15,45 serta nilai rata-rata sebesar 8,017 .
2. Variabel independen X2 yaitu variabel Konsentrasi Kepemilikan Saham (CON_OWN) yang menunjukkan Konsentrasi Kepemilikan Saham dengan nilai minimum sebesar 15,42 dan nilai maksimum sebesar 100,00 serta nilai rata-rata sebesar 54,85 .

3. Variabel independen X3 yaitu variabel Konsentrasi Auditor Eksternal (AUD) yang menunjukkan Auditor Eksternal dengan nilai minimum sebesar 0,0 dan nilai maksimum sebesar 1,00 serta nilai rata-rata sebesar 0,6897 .

4. Variabel independen X4 yaitu variabel Konsentrasi Umur Listing Perusahaan (AGE) yang menunjukkan Konsentrasi Umur Listing Perusahaan dengan nilai minimum sebesar 0,00 dan nilai maksimum sebesar 28,00 serta nilai rata-rata sebesar 11,517.

5. Variabel independen X5 yaitu variabel Komisaris Independen (INED) yang menunjukkan Komisaris Independen dengan nilai minimum sebesar 0,33 dan nilai maksimum sebesar 1,00 serta nilai rata-rata sebesar 0,5421 .

6. Variabel independen X6 yaitu variabel Komite Audit (SAC) yang menunjukkan Komite Audit dengan nilai minimum sebesar 0,00 nilai maksimum sebesar 0,75 serta nilai rata-rata sebesar 0,3952 .

7. Variabel independen X7 yaitu variabel Ukuran Perusahaan (SIZE), yang menunjukkan ukuran perusahaan dengan nilai minimum sebesar 0,858 dan nilai maksimum sebesar 4,497 serta nilai rata-rata sebesar 0,81826 . 
Tabel 2

Statistik Deskriptip Variabel Penelitian

\begin{tabular}{|c|c|c|c|c|c|}
\hline & N & Minimum & Maximum & Mean & Std. Deviation \\
\hline ICD & 29 &, 18 &, 64 &, 4010 &, 11512 \\
LEV & 29 &, 45 & 15,45 & 8,0168 & 3,99807 \\
CON_OWN & 29 & 15,42 & 100,00 & 54,8511 & 24,61883 \\
AUD & 29 &, 00 & 1,00 &, 6897 &, 47082 \\
AGE & 29 &, 00 & 28,00 & 11,5172 & 7,65609 \\
INED & 29 &, 33 & 1,00 &, 5421 &, 13399 \\
SAC & 29 &, 00 &, 75 &, 3952 &, 14951 \\
SIZE & 29 & 0,858 & 4,497 & 0,81826 & 121479,87999 \\
Valid N & 29 & & & & \\
(listwise) & & & & & \\
\hline
\end{tabular}

Sumber: Data Diolah

\section{Uji Asumsi Klasik}

\section{Uji Normalitas}

Uji normalitas dilakukan dengan menggunakan histogram Normal Probability Plot dan uji analisis OneSample Kolmogorof-Smirnof seperti terlihat pada Gambar 1 dan Tabel 3.

Tabel 3 tentang hasil uji normalitas dengan One-Sample KolmogorofSmirnof menunjukkan bahwa nilai Asymp. Sig sebesar 0,952 lebih besar dari 0,05 yang berarti data tersebut dapat dinyatakan terdistribusi normal, sehingga data layak untuk dilakukan uji regresi.

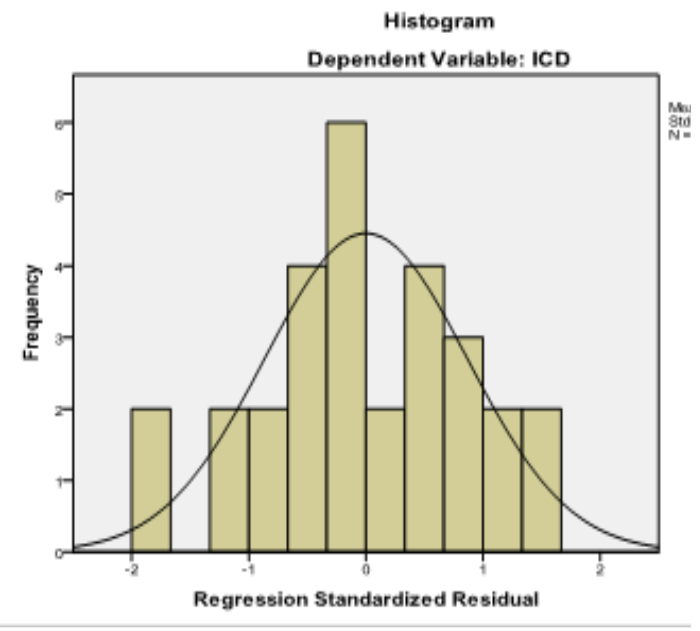

Gambar 1

Histogram Normal Probability Plot
Tabel 3

Tabel Uji One-Sample KolmogorofSmirnof

\begin{tabular}{|l|l|r|}
\hline $\mathbf{N}$ & 29 \\
\hline $\begin{array}{l}\text { Normal } \\
\text { Parameters }\end{array}$ & Mean &, 0000000 \\
\cline { 2 - 3 } & $\begin{array}{l}\text { Std. } \\
\text { Deviation }\end{array}$ &, 09072032 \\
\hline $\begin{array}{l}\text { Most Extreme } \\
\text { Differences }\end{array}$ & Absolute & 0,96 \\
\cline { 2 - 3 } & Positive & 0,72 \\
\cline { 2 - 3 } & Negative & 0,96 \\
\hline Kolmogorov-Smimov Z & 0,517 \\
\hline \multicolumn{2}{|l|}{ Asymp. Sig. (2-tailed) } & 0952 \\
\hline
\end{tabular}

Sumber: Data Diolah

\section{Uji Heteroskedastisitas}

Uji ini dilakukan dengan uji statsitik Glejser. Uji tersebut dilakukan dengan meregresi nilai absolute residual (Abs_Res1) sebagai variabel dependen dengan variable independen. Hasil uji nilai absolute residual (Abs_Res1), dapat dilihat pada Tabel 4. 
Tabel 4

Uji Statistik Spearman's RankCorrelation

\begin{tabular}{|c|c|c|c|c|c|}
\hline \multirow[b]{2}{*}{ Model } & \multicolumn{2}{|c|}{$\begin{array}{c}\text { Uns tandardized } \\
\text { Coefficients }\end{array}$} & \multirow{2}{*}{$\begin{array}{c}\text { S tandardized } \\
\text { Coefficients } \\
\text { Beta } \\
\end{array}$} & \multirow[b]{2}{*}{$t$} & \multirow[b]{2}{*}{ Sig. } \\
\hline & B & Std. Etror & & & \\
\hline (Constant) & 158 &, 125 & & 1,259 &, 222 \\
\hline LEV & , 004 & ,006 & ,124 & ,608 &, 550 \\
\hline CON_OW & , 000 & ,001 &, 054 &, 287 &, 777 \\
\hline $\mathrm{N}$ & & & & & \\
\hline AUD & , 060 & 051 &, 246 & 1,178 &, 252 \\
\hline AGE & , 004 & ,003 & 270 & 1,509 & 146 \\
\hline INED & , 120 & ,176 & 140 & 682 & ,503 \\
\hline SAC &, 052 &, 142 &, 068 &, 365 & ,719 \\
\hline SIZE & 3,23 & ,000 & .341 & 1,692 & , 105 \\
\hline
\end{tabular}

a. Dependent Variable: Abs_Res1

Sumber: Data Diolah

Hasil uji Glejser menyatakan tidak terdapat heteroskedastisitas bila nilai dari signifikansi Abs_Res terhadap masing masing variabel independen lebih besar dari tingkat kepercayaan 0,05. Dalam penelitian ini hasil uji Glejser menyatakan bahwa nilai Signifikansi absres seluruh variabel independen mempunyai nilai $>0,05$.

\section{Uji Multikolinearitas}

Uji multikolinearitas merupakan pengujian yang dilakukan dengan melihat korelasi antara variabel independen dengan nilai tolerance dan nilai Variable Independen Factor (VIF). Model regresi dinyatakan tidak terjadi multikolinearitas, jika mempunyai nilai tolerance di bawah 1 dan nilai VIF di bawah 10. Hasil uji multikolinearitas pada penelitian ini dapat dilihat pada Tabel 5.
Tabel 5

Uji Multikolinearitas

\begin{tabular}{|l|r|r|}
\hline \multirow{2}{*}{ Model } & \multicolumn{2}{|c|}{ Collinearity Statistics } \\
\cline { 2 - 3 } & Tolerance & \multicolumn{1}{c|}{ VIF } \\
\hline 1 (Constant) & & \\
CON_OWN &, 929 & 1,076 \\
AUD &, 686 & 1,457 \\
AGE &, 950 & 1,052 \\
INED &, 829 & 1,206 \\
SAC &, 878 & 1,140 \\
SIZE &, 730 & 1,370 \\
\hline
\end{tabular}

Sumber: Data Diolah

Berdasarkan hasil uji pada Tabel 5 tersebut di atas, dapat diketahui bahwa nilai tolerance dalam penelitian ini di bawah 1 dan nilai VIF di bawah 10. Hal tersebut menjelaskan bahwa dalam penelitian ini tidak terdapat multikolinearitas.

\section{Uji Autokorelasi}

Uji autokorelasi dilakukan dengan menggunakan nilai Uji Durbin Watson, dengan ketentuan sebagai berikut:

$$
\begin{aligned}
(4-\mathrm{dL})<\mathrm{DW}<4 & : \text { Ho ditolak, } \\
& \begin{array}{l}
\text { terdapat } \\
\text { autokorelasi }
\end{array} \\
(4-\mathrm{dU})<\mathrm{DW}<(4-\mathrm{dL}): & \text { Ragu ragu } \\
\mathrm{dU} \quad<\mathrm{DW}<(4-\mathrm{dU}): & \text { Ho diterima, } \\
& \text { tidak terdapat } \\
& \text { autokorelasi } \\
\mathrm{dL} \quad<\mathrm{DW}<\mathrm{dU} \quad & : \text { Ragu ragu } \\
0 \quad<\mathrm{DW}<\mathrm{dL} \quad & \text { Ho ditolak, } \\
& \text { terdapat } \\
& \text { autokorelasi }
\end{aligned}
$$

Dalam penelitian ini hasil uji DurbinWatson dapat dilihat pada Tabel 6. 
Tabel 6

Hasil Uji Durbin-Watson

\begin{tabular}{|l|c|r|r|r|c|}
\hline Model & $R$ & $\begin{array}{c}\mathrm{R} \\
\text { Square }\end{array}$ & $\begin{array}{c}\text { Adjusted } \\
\mathrm{R} \\
\text { Square }\end{array}$ & $\begin{array}{c}\text { StdError } \\
\text { of the } \\
\text { Estimasi }\end{array}$ & $\begin{array}{c}\text { Durbin } \\
\text { Watson }\end{array}$ \\
\hline 1 &, $616^{\mathrm{a}}$ &, 379 &, 172 &, 10475 & 2,179 \\
\hline
\end{tabular}

Sumber: Data Diolah

Dari data pada Tabel 6 diketahui nilai uji Durbin-Watson sebesar 2,179. Du sebesar 1,798 lebih kecil dari 2,179, dan Nilai DW lebih kecil dari 4-du (41,798). Jadi dapat dikatakan bahwa pada penelitian ini tidak terdapat autokorelasi, sehingga $\mathrm{H} 0$ diterima.

\section{Pengujian Hipotesis}

Uji asumsi klasik yang dilakukan di atas menunjukkan bahwa kualitas data penelitian tidak mengalami penyimpangan data atau bias. Hal tersebut menunjukkan bahwa model regresi yang diuji tidak mengalami penyimpangan, sehingga persamaan regresi yang akan diuji dinyatakan dapat digeneralisasikan. Namun demikian ketepatan persamaan regresi perlu diukur goodness of fit-nya. Hal tersebut dapat diukur dengan menguji koefisien determinan $\left(\mathrm{R}^{2}\right)$ dari nilai uji statistik $F$ dan nilai uji statistik $\mathrm{t}$.

\section{Uji Koefisien Determinasi $\left(\mathbf{R}^{\mathbf{2}}\right)$}

Uji koefisien determinasi mengukur kemampuan model dalam menerangkan variabel dependen. Hasil Pengujian dalam penelitian ini dapat dilihat pada Tabel 7.

Tabel 7

Hasil Pengujian Koefisien Determinasi

\begin{tabular}{|l|c|c|c|c|}
\hline Model & $\mathrm{R}$ & $\begin{array}{c}\mathrm{R} \\
\text { Square }\end{array}$ & $\begin{array}{c}\text { Adjusted } \\
\mathrm{R} \\
\text { Square }\end{array}$ & $\begin{array}{c}\text { Std.Error } \\
\text { of the } \\
\text { Estimasi }\end{array}$ \\
\hline 1 &, $616^{\mathrm{a}}$ &, 379 &, 172 &, 10475 \\
\hline
\end{tabular}

Sumber: Data Diolah
Data Tabel 7 menunjukkan nilai koefisien determinasi ( $\mathrm{R}$ Square) R2 sebesar 0,379. Hal tersebut menjelaskan bahwa variabel independen berupa Leverage (LEV), Konsentrasi Kepemilikan (CON-OWN), Akuntan Eksternal (AUD), Umur Listing (AGE), Proporsi Komisaris Independen (INED), Komite Audit (SAC) dan Ukuran Perusahaan (SIZE) dapat menjelaskan sebesar $37,9 \%$ terhadap variabel dependen, sedangkan sisanya dijelaskan oleh faktor lain di luar model persamaan regresi.

Sedangkan Std. Error of the Estimate (SEE) sebesar 0,10475 menjelaskan bahwa model regresi dalam penelitian ini tepat dalam memprediksi variabel dependen. Makin kecil nilai SEE maka model regresi semakin tepat dalam memprediksi variabel dependen.

\section{Uji Pengaruh Simultan (F test)}

Uji Simultan (F Tes) menguji apakah semua variabel independen dalam persamaan memiliki pengaruh secara bersama-sama atau simultan terhadap variabel dependen. Dalam penelitian ini hasil uji terhadap nilai $F$ test dapat dilihat pada Tabel 8 .

\section{Tabel 8}

Uji simultan antara variabel independen dengan variabel dependen ANOVA ${ }^{b}$

\begin{tabular}{|ll|r|r|r|r|r|}
\hline \multicolumn{2}{|l|}{ Model } & $\begin{array}{r}\text { Sum of } \\
\text { Squares }\end{array}$ & df & $\begin{array}{r}\text { Mean } \\
\text { Square }\end{array}$ & F & Sig. \\
\hline $1 \quad$ Regression &, 141 & 7 &, 020 & 1,831 &, 0343 \\
& Residual &, 230 & 21 &, 011 & & \\
\multicolumn{2}{|c|}{ Total } &, 371 & 28 & & & \\
\hline
\end{tabular}

Sumber: Data Diolah 
Berdasarkan data Tabel 8 dapat dinyatakan bahwa nilai $\mathrm{F}$ hitung sebesar 1,831 dan tingkat signifikansi lebih kecil dari 0,05 yaitu sebesar 0,034, maka dapat disimpulkan bahwa model regresi dapat dipakai untuk memprediksi seluruh variabel independen yang terdiri dari: JEP, LEV, CON-OWN, AUD, AGE, INED, SAC, SIZE) secara simultan (bersama-sama).

\section{Uji Pengaruh Parsial (t test)}

Uji statistik t pada dasarnya menunjukkan seberapa jauh pengaruh satu variabel independen terhadap variabel dependen dengan menganggap variabel independen yang lainnya konstan. Hasil pengujian parsial ( $\mathrm{t}$ test) dapat dilihat pada Tabel 9.

\section{Tabel 9}

\section{Hasil Perhitungan Pengujian Parameter Individual}

Coefficients $^{a}$

\begin{tabular}{|c|c|c|c|c|c|}
\hline \multirow[b]{2}{*}{ Model } & \multicolumn{2}{|c|}{$\begin{array}{l}\text { Unstandardizec } \\
\text { Coefficients }\end{array}$} & \begin{tabular}{|l|} 
Standardized \\
Coefficients
\end{tabular} & & \multirow[b]{2}{*}{ Sig. } \\
\hline & $B$ & $\begin{array}{l}\text { Std. } \\
\text { Error }\end{array}$ & Beta & & \\
\hline 1 (Constant) & 158 & 125 & & 1,259 & .222 \\
\hline LEV & 004 &, 006 &, 124 & 608 & 550 \\
\hline CON_OWN & 000 &, 001 &, 054 & 287 & 777 \\
\hline AUD & 060 &, 051 & 246 & 1,178 & 252 \\
\hline AGE & .004 &, 003 & 270 & 1,509 & 146 \\
\hline INED & 120 & 176 &, 140 & 682 & 503 \\
\hline $\mathrm{SAC}$ & 052 & 142 &, 068 & 365 & 719 \\
\hline SIZE & 032 & 000 & 341 & 1,692 & 105 \\
\hline
\end{tabular}

Berdasarkan tabel diatas dapat ditarik persamaan regresi sebagai berikut :

$\mathrm{Y}=0,158+0,004 \mathrm{X} 1+0,000 \mathrm{X} 2+$ $0,060 \mathrm{X} 3+0,004 \mathrm{X} 4+0,120 \mathrm{X} 5+$ $0,052 \times 6+0,032 \times 7+\varepsilon$.

Dari persamaan regresi di atas dapat disimpulkan bahwa:
1. Nilai konstanta sebesar $(+)$ 0,158 . Hal tersebut menjelaskan bahwa tanpa adanya pengaruh dari leverage, konsentrasi kepemilikan, kantor akuntan, umur listing, komisaris independen, komite audit dan ukuran perusahaan, maka akan terjadi kenaikan pengungkapan intellectual capital sebesar 0,158 atau jika variabel independen dianggap konstan, maka akan terjadi kenaikan variabel dependen sebesar 0,158 .

2. Nilai koefisien regresi variabel leverage (LEV-X1) sebesar $(+)$ 0,004 . Hal tersebut menjelaskan bahwa setiap kenaikan proporsi leverage dengan asumsi variabel lainnya tetap (cateris paribus), maka intellectual capital disclosure akan mengalami perubahan dengan arah yang sama.

3. Nilai koefisien regresi dari variabel konsentrasi kepemilikan (CON OWN-X2) sebesar (+) 0,000 . Hal tersebut menjelaskan bahwa setiap kenaikan konsentrasi kepemilikan dengan asumsi variabel lainnya tetap (cateris paribus), maka intellectual capital disclosure akan mengalami perubahan dengan arah yang sama.

4. Nilai koefisien regresi dari variabel pengaruh auditor eksternal (AUD-X3) sebesar (+) 0,060 . Hal tersebut menjelaskan bahwa setiap perubahan pengaruh auditor eksternal dengan asumsi variabel lainnya tetap (cateris paribus), maka 
intellectual capital disclosure akan mengalami perubahan dengan arah yang sama.

5. Nilai koefisien regresi dari variabel umur listing perusahaan (AGE-X4) sebesar (+) 0,004. Hal tersebut menjelaskan bahwa setiap perubahan umur listing perusahaan dengan asumsi variabel lainnya tetap (cateris paribus), maka intellectual capital disclosure akan mengalami perubahan dengan arah yang sama.

6. Nilai koefisien regresi variabel proporsi komisaris independen (INED-X5) sebesar (+) 0,120. Hal tersebut menjelaskan bahwa setiap perubahan proporsi komisaris independen dengan asumsi variabel lainnya tetap (cateris paribus), maka intellectual capital disclosure akan mengalami perubahan dengan arah yang sama.

7. Nilai koefisien regresi dari variabel komite audit (SACX6) sebesar (+) 0,052. Hal tersebut menjelaskan bahwa setiap perubahan komite audit dengan asumsi variabel lainnya tetap (cateris paribus), maka intellectual capital disclosure akan mengalami perubahan dengan arah yang sama.

8. Nilai koefisien regresi variabel ukuran perusahaan (SIZE-X7) sebesar $+0,032$. Hal tersebut menjelaskan bahwa setiap kenaikan ukuran perusahaan dengan asumsi variabel lainnya tetap (cateris paribus), maka intellectual capital disclosure akan mengalami perubahan dengan arah yang sama.

\section{PEMBAHASAN \\ Pengujian Pengaruh Leverage terhadap Pengungkapan Intellectual Capital}

Pengujian dengan menggunakan regresi berganda pada hipotesis pengaruh leverage terhadap pengungkapan intellectual capital menunjukkan nilai koefisien regresi variabel leverage sebesar $+0,004$. Hal tersebut menjelaskan bahwa leverage mempunyai pengaruh negatif terhadap pengungkapan intellectual capital. Sedangkan nilai signifikansi sebesar 0,550 lebih besar dari tingkat kepercayaan $\alpha=0,05$ menjelaskan bahwa variabel leverage secara parsial mempunyai pengaruh yang tidak signifikan terhadap pengungkapan intellectual capital. Berdasarkan hasil tersebut dapat disimpulkan bahwa hipotesa H1 yang menyatakan bahwa ada pengaruh positif yang signifikan dari leverage (X1) terhadap intellectual capital disclosure (Y) ditolak.

Hasil penelitian ini konsisten dengan hasil penelitian yang dilakukan oleh Wardhani (2013) pada perusahaan manufaktur di Indonesia yang menunjukkan bahwa tidak terdapat pengaruh yang signifikan antara leverage dengan tingkat pengungkapan intellectual capital disclosure (ICD). Selain itu peneliti ini juga konsisten dengan penelitian yang dilakukan oleh Whiting and Woodcook (2011) yang menunjukkan tidak ada hubungan antara leverage perusahaan dengan pengungkapan intellectual capital pada perusahaan di New Zealand. 


\section{Pengujian Pengaruh Konsentrasi Kepemilikan terhadap Pengung- kapan Intellectual Capital (ICD)}

Pengujian dengan menggunakan regresi berganda pada hipotesis pengaruh konsentrasi kepemilikan terhadap pengungkapan intellectual capital menunjukkan nilai koefisien regresi variabel konsentrasi kepemilikan sebesar $+0,000$. Hal tersebut menjelaskan bahwa konsentrasi kepemilikan mempunyai pengaruh positif terhadap pengungkapan intellectual capital. Sedangkan nilai signifikansi sebesar 0,777 lebih besar dari tingkat kepercayaan $\alpha$ $=0.05$ menjelaskan bahwa variabel konsentrasi kepemilikan secara parsial mempunyai pengaruh yang tidak signifikan terhadap pengungkapan intellectual capital. Berdasarkan hasil tersebut dapat disimpulkan hipotesis $\mathrm{H} 2$ yang menyatakan ada pengaruh negatif yang signifikan dari konsentrasi kepemilikan (X2) terhadap intellectual capital disclosure (Y) ditolak.

Hasil pengujian dalam penelitian ini konsisten dengan hasil penelitian yang dilakukan oleh Wardhani (2013) yang menyatakan bahwa tidak terdapat pengaruh antara konsentrasi kepemilikan dengan intellectual capital disclosure. Selain itu penelitian ini juga konsisten dengan penelitian White et al. (2007) yang menunjukkan tidak ada hubungan antara konsentrasi kepemilikan perusahaan dengan pengungkapan intellectual capital. Namun demikian penelitian ini memberikan hasil berbeda dengan penelitian yang dilakukan oleh Singh and Zahn (2008), yang menjelaskan bahwa kepemilikan perusahan yang lebih besar penyebaran kepemilikannya akan lebih mengung- kapkan informasi lebih banyak untuk mengurangi biaya agency dan informasi asimetri.

\section{Pengujian Pengaruh Auditor Eksternal terhadap Pengungkapan Intellectual Capital (ICD)}

Pengujian dengan menggunakan regresi berganda pada hipotesis pengaruh auditor eksternal terhadap pengungkapan intellectual capital menunjukkan nilai koefisien regresi variabel auditor eksternal sebesar $+0,060$, hal tersebut menjelaskan bahwa auditor eksternal mempunyai pengaruh positif terhadap pengungkapan intellectual capital. Sedangkan nilai signifikansi sebesar 0,252 lebih besar dari tingkat kepercayaan $\alpha=0.05$ menjelaskan bahwa variabel auditor eksternal secara parsial mempunyai pengaruh yang tidak signifikan terhadap pengungkapan intellectual capital. Berdasarkan hasil tersebut dapat disimpulkan bahwa hipotesis $\mathrm{H} 3$ yang menyatakan ada pengaruh positif yang signifikan dari auditor eksternal (X3) terhadap intellectual capital disclosure $(\mathrm{Y})$ ditolak.

Penelitian ini tidak konsisten dengan penelitian yang dilakukan oleh Wardhani (2013), Whiting and Woodcock (2011) dan Barako (2007) yang menyatakan bahwa terdapat hubungan antara jenis perusahaan audit dan pengungkapan intellectual capital, di mana dapat terjadi, karena perusahaan audit yang besar memiliki reputasi untuk melestarikan dan mendorong klien mereka menyediakan pengungkapan intellectual capital daripada membatasi pengungkapan perilaku. Namun dalam penelitian ini memberikan hasil yang berbeda, bahwa tidak 
terdapat pengaruh yang signifikan terhadap auditor eksternal dengan pengungkapan intellectual capital.

\section{Pengujian Pengaruh Umur Listing Perusahaan terhadap Pengung- kapan Intellectual Capital (ICD)}

Pengujian dengan menggunakan regresi berganda pada hipotesis pengaruh umur listing perusahaan terhadap pengungkapan intellectual capital menunjukkan nilai koefisien regresi variabel umur listing perusahaan sebesar $+0,004$, hal tersebut menjelaskan bahwa umur listing perusahaan mempunyai pengaruh positif terhadap pengungkapan intellectual capital. Sedangkan nilai signifikansi sebesar 0,146 lebih besar dari tingkat kepercayaan $\alpha=0,05$ menjelaskan bahwa variabel umur listing perusahaan secara parsial mempunyai pengaruh yang tidak signifikan terhadap pengungkapan intellectual capital. Berdasarkan hasil tersebut dapat disimpulkan bahwa hipotesis $\mathrm{H} 4$ yang menyatakan bahwa ada pengaruh negatif yang signifikan dari umur listing perusahaan (X4) terhadap intellectual capital disclosure (Y) ditolak.

Hasil penelitian ini konsisten dengan penelitian yang dilakukan oleh Wardhani (2013) yang menyatakan bahwa tidak terdapat pengaruh yang signifikan umur listing terhadap intellectual capital disclosure (ICD). Namun demikian hasil penelitian ini tidak konsisten dengan penelitian yang dilakukan oleh Barnes and Walker (2006) dalam Li et al. (2008), Bukh et al. (2005) yang menjelaskan bahwa perusahaan yang telah mapan atau lebih tua kurang berisiko. Oleh karena itu perusahaan yang lebih tua akan cenderung memberikan pengungkapan kurang dari pada perusahaan lebih muda yang berisiko. Perusahaan yang lebih muda lebih berisiko tinggi, sehingga perusahaan tersebut akan lebih cenderung untuk mengungkapkan informasi dalam upaya untuk menurunkan profil risiko dari perusahaannya.

\section{Pengujian Pengaruh Proporsi Komisaris Independen terhadap Pengungkapan Intellectual Capital (ICD)}

Pengujian dengan menggunakan regresi berganda pada hipotesis pengaruh proporsi komisaris independen terhadap pengungkapan intellectual capital menunjukkan nilai koefisien regresi variabel proporsi komisaris independen sebesar $+0,120$. Hal tersebut menjelaskan bahwa proporsi komisaris independen mempunyai pengaruh positif terhadap pengungkapan intellectual capital. Sedangkan nilai signifikansi sebesar 0,503 lebih besar dari tingkat kepercayaan $\alpha=0.05$ menjelaskan bahwa variabel proporsi komisaris independen perusahaan secara parsial mempunyai pengaruh yang tidak signifikan terhadap pengungkapan intellectual capital. Berdasarkan hasil tersebut dapat disimpulkan bahwa hipotesis $\mathrm{H} 5$ yang menyatakan bahwa ada pengaruh positif yang signifikan dari proporsi komisaris independen (X5) terhadap intellectual capital disclosure (Y) ditolak.

Hasil penelitian ini konsisten dengan penelitian yang dilakukan oleh Wardhani (2013) yang menyatakan bahwa tidak terdapat pengaruh yang 
signifikan terhadap intellectual capital disclosure. Namun demikian penelitian ini tidak konsisten dengan penelitian yang dilakukan oleh White et al. (2007), Cerbioni and Parbonetti (2007), Li et al. (2008) yang dalam penelitiannya menyatakan bahwa pengungkapan sukarela yang dilakukan perusahaan mempertimbangkan komposisi dewan independen sebagai faktor penentu dari pengungkapan intellectual capital. Jadi proporsi dewan komisaris berhubungan secara positif dengan kemampuan dewan untuk mempengaruhi keputusan pengungkapan sukarela.

\section{Pengujian Pengaruh Komite Audit terhadap Pengungkapan Intellectual Capital (ICD)}

Pengujian dengan menggunakan regresi berganda pada hipotesis pengaruh komite audit terhadap pengungkapan intellectual capital menunjukkan nilai koefisien regresi variabel komite audit sebesar $+0,052$. Hal tersebut menjelaskan bahwa komite audit mempunyai pengaruh positif terhadap pengungkapan intellectual capital. Sedangkan nilai signifikansi sebesar 0,719 lebih besar dari tingkat kepercayaan $\alpha$ $=0.05$ menjelaskan bahwa variabel komite audit secara parsial mempunyai pengaruh yang tidak signifikan terhadap pengungkapan intellectual capital. Berdasarkan hasil tersebut dapat disimpulkan bahwa hipotesis H6 yang menyatakan bahwa ada pengaruh yang signifikan dari ukuran komite audit (X6) terhadap intellectual capital disclosure (Y) ditolak.

Hasil penelitian ini tidak konsisten dengan penelitian yang dilakukan oleh Wardhani (2013), Ho and Wong
(2001) dalam Gan et al. (2008), Li, et al. (2008) yang menemukan bahwa semakin luas ukuran komite audit akan meningkatkan juga pengungkapan (disclosure) perusahaan. Komite audit diharapkan memiliki dampak yang signifikan terhadap pengungkapan nilai informasi yang relevan terkait dengan elemen yang membentuk intellectual capital perusahaan, karena komite audit adalah suatu fungsi yang bukan hanya dari struktur dan komposisi dari dewan komisaris, tetapi juga dari subkomite dewan komisaris di mana banyak proses dan keputusan penting dilakukan dan diawasi oleh komite audit.

\section{Pengujian Pengaruh Ukuran Perusahaan terhadap Pengungkap- an Intellectual Capital (ICD)}

Pengujian dengan menggunakan regresi berganda pada hipotesis pengaruh ukuran perusahaan terhadap pengungkapan intellectual capital menunjukkan nilai koefisien regresi variabel ukuran perusahan sebesar $+0,032$. Hal tersebut menjelaskan bahwa ukuran perusahaan mempunyai pengaruh positif terhadap pengungkapan intellectual capital. Sedangkan nilai signifikansi sebesar 0,105 lebih besar dari tingkat kepercayaan $\alpha=0,05$ menjelaskan bahwa variabel ukuran perusahaan secara parsial mempunyai pengaruh yang tidak signifikan terhadap pengungkapan intellectual capital. Berdasarkan hasil tersebut dapat disimpulkan bahwa hipotesis H8 yang menyatakan bahwa ada pengaruh positif yang signifikan ukuran perusahaan (X8) terhadap intellectual capital disclosure (Y) ditolak. 
Hasil penelitian ini tidak konsisten dengan penelitian yang dilakukan oleh Wardhani (2013), Bozzolan et al. (2003), Garcia-meca et al. (2005), Petty and Cuganesan (2005) dalam Branco et al. (2010), White et al. (2007), Bruggen et al. (2009) dan Branco et al. (2010) yang menjelaskan bahwa perusahaan besar lebih banyak melakukan pengungkapan karena perusahaan besar lebih sensitif terhadap biaya politik. Selain itu perusahan besar memiliki sumber daya dan pimpinan yang berpengalaman/unggul yang dapat mengurangi biaya untuk menyiapkan informasi yang dibutuhkan oleh perusahaan, sedangkan perusahaan kecil umumnya berada pada situasi persaingan yang ketat dengan perusahaan lain.

\section{KESIMPULAN}

1. Dari hasil uji statistik dapat diketahui bahwa dari 7 variabel dependen perusahaan, tidak terdapat hasil yang signifikan terhadap pengungkapan intellectual capital. Tingkat pengungkapan intellectual capital dalam penelitian ini rata-rata hanya sebesar 37,9\%. Hal tersebut menunjukkan bahwa pengungkapan intellectual capital disclosure di Indonesia sangat rendah.

2. Pada high-IC intensive industries perusahaan sampel $(\mathrm{N})$ sebanyak 44 pengungkapan intellectual capital hanya sebesar $35,47 \%$, sedangkan pada Low-IC intensive industries perusahaan sampel $(\mathrm{N})$ sebanyak 61 pengungkapan intellectual capital yang dilakukan sebesar 33,96\%, perbedaan yang terjadi tidak signifikan hanya sebesar $1,51 \%$.

3. Tingkat signifikansi sebesar 0,034 lebih kecil dari tingkat kepercayaan sebesar 0,05, maka dapat disimpulkan bahwa model regresi ini dapat dipakai untuk memprediksi seluruh variabel independen (LEV, CONOWN, AUD, AGE, INED, SAC, SIZE) secara simultan (bersamasama) berpengaruh signifikan terhadap variabel dependen (ICD) sebesar 0,000. Sedangkan koefisien determinasi ( $R$ Square) sebesar 0,379 menjelaskan bahwa variabel independen bisa menjelaskan sebesar $37,9 \%$ terhadap variabel dependen.

4. Penelitian ini menunjukkan hasil yang tidak signifikan/ditolak, karena perusahaan masih beranggapan bahwa pengungkapan intellectual capital masih bersifat sukarela, sehingga ada kemungkinan perusahaan yang sebenarnya memiliki item-item pengungkapan intellectual capital, namun tidak melakukan pengungkapan pada laporan tahunan perusahaan. Hal tersebut dikarenakan pertimbangan mahalnya biaya yang harus dikeluarkan perusahaan dalam melakukan pengungkapan intellectual capital.

\section{SARAN}

1. Tahun pengamatan yang digunakan dalam penelitian ini relatif pendek, hanya satu tahun. Ada baiknya pada penelitian selanjutnya menambah tahun pengamatan, sehingga dapat melihat bagaimana pola pengungkapan intellectual capital apakah signifikan atau tidak signifikan.

2. Jumlah sampel perusahaan hanya perusahaan yang terdaftar di Bursa Efek Indonesia saja, padahal masih banyak perusahaan yang dapat dijadikan sampel penelitian, sehingga penelitian ini kurang mampu untuk digeneralisasikan. Untuk itu pada penelitian selanjutnya ada baiknya 
sampel tidak hanya terbatas pada perusahaan yang terdaftar di Bursa Efek Indonesia.

\section{DAFTAR KEPUSTAKAAN}

Barako, Dulacha G., 2007, Determinants of Voluntary Disclosures in Kenyan Companies Annual Reports, African Journal of Business Management, Vol. 1, No. 5, page 113-128.

Barnes, E. and M. Walker, 2006, The Seasoned-Equity Issues of UK Firms: Market Reaction and Issuance Method Choice, Journal of Business Finance \& Accounting, Vol. 33, No. 1-2, page 45-78.

Bozzolan, Saverio, Francesco Favotto and Federica Ricceri, 2003, Italian Annual Intellectual Capital Disclosure an Empirical Analysis, Journal of Intellectual Capital, Vol. 4, Issue 4, page 543-558.

Branco, Manuel Castelo, Catarina Delgado, Manuel Sa. and Cristina Sousa, 2010, An Analysis of Intellectual Capital Disclosure by Portuguese Companies, EuroMed Journal of Business, Vol. 5, No. 3, page 258-278.

Bruggen, Alexander, Philip Vergauwen and Mai Dao, 2009, Determinants of Intellectual Capital Disclosure: Evidence from Australia, Management Decision, Vol. 47, No. 2, page 233-245.

Bukh, Per Nikolaj, 2003, Commentary: The Relevance of Intellectual Capital Disclosure: A Paradox?, Accounting, Auditing \& Accountability Journal, Vol. 16, Issue 1, page 49-56.
Bukh, Per Nikolaj, Christian Nielsen, Peter Gormsen and Jan Mouritsen, 2005, Disclosure of Information on Intellectual Capital in Danish IPO Prospectuses, Accounting, Auditing \& Accountability Jour-nal, Vol. 18, Issue 6, page 713-732.

Cerbioni, Fabrizio and Antonio Parbonetti, 2007, Exploring The Effects of Corporate Governance on Intellectual Capital Disclosure: An Analysis of European Biotechnology Companies, European Accounting Review, Vol. 16, No. 4, page $791-826$.

Gan, Kin, Zakiah Saleh and Masoud Abessi, 2008, Corporate Governance, Ownership Structures and Intellectual Capital Disclosures: Malaysian Evidence, The 16th Conference on the Theories and Practices of Securities and Financial Markets, page 1-33.

Garcia-meca, Emma, Isabel Parra, Manuel Larra and Isabel Martinez, 2005, The Explanatory Factors of Intellectual Capital Disclosure to Financial Analysts, European Accounting Review, Vol. 14, Issue 1, page 63-94.

Li, Jing, Richard Pike and Roszaini Haniffa, 2008, Intellectual Capital Disclosure and Corporate Governance Structure in UK Firms. Accounting and Business Re-search, Vol. 38, No. 2, page 137-159.

Petty, Richard M, Suresh Cuganesan, Nigel Finch and Guy Ford, 2009, Intellectual Capital and Valua-tion: Challenges in the Voluntary Disclosure of Value Drivers, Journal of Finance and Accountancy 
Intellectual Capital, page 1-7, www.ssrn.com.

Putnis, Jan, 2012, The Banking Regulation, (Third Edition), Law Business Research Ltd., London.

Singh, Inderpal and J-L. W. Mitchell Van der Zahn, 2008, Determinants Of Intellectual Capital Disclosure in Prospectuses of Initial Public Offerings, Accounting and Business Research, Vol. 38, No. 5, page 409-431.

Suhardjanto, Djoko dan Mari Wardhani, 2010, Praktek Intellectual Capital Disclosure Perusahaan yang Terdaftar di Bursa EFek Indonesia, JAAI, Vol. 14, No. 1, page 71-85.

Tayles, Mike, Richard H. Pike, and Saudah Sofian, 2007, Intellectual Capital, Management Accounting Practice and Corporate Performance: Perceptions of Managers, Accounting, Auditing \& Accountability Journal, Vol. 20, Issue 4, page 522-548.
Wardhani, Agung Sri, 2013, Pengaruh Karakteristik Perusahaan Terhadap Intellectual Capital Disclosure (ICD) pada Perusahaan Non Keuangan Yang terdaftar di Bursa Efek Indonesia, Jurnal Bisnis Perspektif (BIPs), Vol. 5, No.1, hal. 86-12.

White, Gregory, Alina Lee and Greg Tower, 2007, Drivers of Voluntary Intellectual Capital Disclosure in Listed Biotechnology Companies, Journal of Intellectual Capital, Vol. 8 , No. 3, page 517-537.

Whiting, Rosalind $H$. and James Woodcock, 2011, Firm Characteristics and Intellectual Capital Disclosure by Australian Companies, Journal of Human Resource Costing \& Accounting. Vol. 15, Issue 2, page102 - 126. 